Article

\title{
Disinfection Performance in Wastewater Stabilization Ponds in Cold Climate Conditions: A Case Study in Nunavut, Canada
}

\author{
Lei Liu, Alan MacDougall, Geof Hall and Pascale Champagne* \\ Department of Civil Engineering, Queen's University, 58 University Ave., Kingston, ON K7L 3N6, Canada; \\ liu.lei@queensu.ca (L.L.); 14am87@queensu.ca (A.M.); gh26@queensu.ca (G.H.) \\ * Correspondence: pascale.champagne@queensu.ca; Tel.: +1-613-533-3053
}

Received: 10 November 2017; Accepted: 11 December 2017; Published: 14 December 2017

\begin{abstract}
Disinfection processes in passive wastewater treatment systems, which are dependent on natural purification, can be greatly influenced by environmental factors. In the Canadian Arctic, the passive systems face more challenges due to the extreme environmental conditions. The new Wastewater Systems Effluent Regulations (WSER) were implemented in Canada in 2012. Currently, they do not apply in the far North due to the limited wastewater treatment infrastructure in northern communities. In the summer of 2015, a field investigation was conducted to Pond Inlet, Nunavut, to assess the pathogen removal and inactivation of a wastewater stabilization pond (WSP). Sunlight disinfection was considered only effective at the water surface. The system achieved 0.76-1.2 log removal of E. coli and 0.79-1.02 log removal of total coliforms during the treatment season in 2015 . Prior to annual decant, the average concentration of E. coli was $1.3 \times 10^{6} \mathrm{CFU} / 100 \mathrm{~mL}$ in the WSP, which exceeded discharge guidelines of $10^{4}$ to $10^{6} \mathrm{CFU} / 100 \mathrm{~mL}$ set by the Nunavut Water Board (NWB). Existing WSP disinfection models, which were typically designed for temperate or tropical regions, were selected to study their viability to predict the pathogen removal of Arctic WSPs. In general, the models over-predicted disinfection performance by an order of magnitude or more, and some were unable to replicate trends in the data. A modified model for northern WSPs should be developed in order to accurately predict disinfection performance.
\end{abstract}

Keywords: pathogen removal; wastewater stabilization ponds; E. coli removal; sunlight disinfection; modeling; case study

\section{Introduction}

Nunavut is the largest Canadian territory by land mass, with a population of 31,906 people dispersed over 2 million square kilometers and with many communities only accessible by plane. Few of these remote communities exceed populations of more than 2000 people [1]. The majority of communities in the Canadian Arctic use passive wastewater treatment systems, such as WSPs and constructed wetlands (CWs), as the extreme climatic conditions and remote locations pose challenges to the implementation of conventional wastewater treatment infrastructure. Moreover, due to the continuous permafrost conditions in the Canadian Arctic, it is impractical to build piped systems or buried infrastructure to transport sewage from households to a centralized wastewater treatment facility. Therefore, most northern communities rely on sewage trucks for collection and transport of wastewater [1].

WSPs, in comparison to conventional wastewater treatment technologies, have several advantages including ease of operation, lower cost, and lower maintenance. Therefore, they have been employed in small, rural, and remote communities around the world as an economical and sustainable alternative for treating wastewater [2,3]. WSPs attenuate organic and nutrient loads and have been reported 
to achieve excellent pathogen removal efficiencies through naturally occurring biological, chemical, and physical treatment mechanisms [4-7]. However, Arctic environmental conditions such as short summers and lower temperatures can greatly affect their performance, leaving them less effective than WSPs operated in temperate or tropical climates [8,9]. In Northern Canada, the summer season is generally from middle of June to early September with an average temperature of $7^{\circ} \mathrm{C}$. The wastewater remains frozen in WSPs for the remainder of the year. Pathogen removal is one area of WSP operation where Arctic environmental conditions pose challenges.

Potential pathogens in wastewater effluents include various genera of bacteria, viruses, protozoa, and helminth ova, whose presence in output wastewater can negatively affect receiving environments and human health. Disinfection quality is evaluated through the assessment of indicator organisms, typically Escherichia coli (E. coli), fecal coliforms, or total coliforms. Disinfection in WSPs relies on environmental factors, such as sunlight, $\mathrm{pH}$, dissolved oxygen (DO), temperature, as well as attachment and sedimentation [10-12]. Previous studies have noted that solar radiation is likely the most potent factor contributing to disinfection in WSPs $[4,13,14]$, with sunlight inactivation more than one order of magnitude higher than dark inactivation rates $[9,15]$. The Northern sun, with an extended photoperiod of $24 \mathrm{~h}$ of daylight in summers and a small azimuth, could highly influence pathogen removal efficiency in Arctic WSPs. High pH and DO levels have commonly been observed in facultative and maturation ponds due to algal activity. $\mathrm{pH}$ levels higher than 9 have been reported to be effective in the inactivation or removal of indicator organisms, as high $\mathrm{pH}$ can cause damage to the cell DNA [16-19]. An increase in DO concentration would likely increase the effect of photo-oxidation, and the light inactivation of E. coli and Enterococci have been reported to increase with increasing DO concentrations [20]. To date, studies linking disinfection to temperature have been inconsistent in their findings [8,9,21-27].

Modelling disinfection can be useful for both optimizing performance and design considerations in WSPs. Over the past 40 years, several models have been developed for predicting and optimizing disinfection performance of WSPs, each considering a unique combination of environmental factors $[9,13,26,28,29]$. The first of these WSP disinfection models was the Marais model, which has typically been used for maturation pond design [28]. Existing models were generally designed, calibrated and validated using data from temperate or tropical regions, which may not be representative of cold climate WSP operations. To date, disinfection models have not been developed specifically for cold climate WSP applications.

Wastewater treatment facilities in Nunavut are required to meet territorial effluent quality criteria. These criteria are regulated by the Nunavut Water Board (NWB) and are enforced by Indigenous and Northern Affairs Canada (INAC). The discharge regulations vary on a case-by-case basis, with target effluent concentrations ranging from $10^{4}-10^{6}$ colony forming units per $100 \mathrm{~mL}$ (CFU/100 mL) of E. coli. Previous studies on WSPs in Nunavut have found that discharged effluents inconsistently meet the NWB criteria [30]. Currently, there is limited data on the disinfection performance of single-celled WSPs under extreme climatic conditions such as those found in the Arctic. In addition, the mechanisms affecting the performance of these systems during the summer treatment season with respect to pathogen reduction needs to be investigated more fully. The objectives of this study were to monitor an Arctic WSP to assess its disinfection performance and ability to meet regulatory effluent guidelines and to test existing disinfection models using the data collected to determine whether these models represent the performance of cold climate WSPs.

\section{Materials and Methods}

\subsection{Study Site}

Pond Inlet $\left(72^{\circ} 41^{\prime} 57^{\prime \prime} \mathrm{N}, 77^{\circ} 57^{\prime} 33^{\prime \prime} \mathrm{W}\right)$ is a small, predominantly Inuit community located on northern Baffin Island, Nunavut, with a population in 2014 of approximately 1600. Pond Inlet uses a single-cell WSP to treat its sewage. The WSP was designed to be a facultative pond with depths ranging from $1.5 \mathrm{~m}$ to $3 \mathrm{~m}$. Profile and plain views of the Pond Inlet WSP bathymetry are shown 
in Figure 1, along with the sampling locations for this study. The estimated volume of the pond is $100,000 \mathrm{~m}^{3}$ and the daily inflow is approximately $104 \mathrm{~m}^{3} / \mathrm{d}$. The summer treatment season is generally from the middle of June to early September, and the WSP is decanted directly to the Arctic Ocean at the end of the treatment season, prior to freezing.

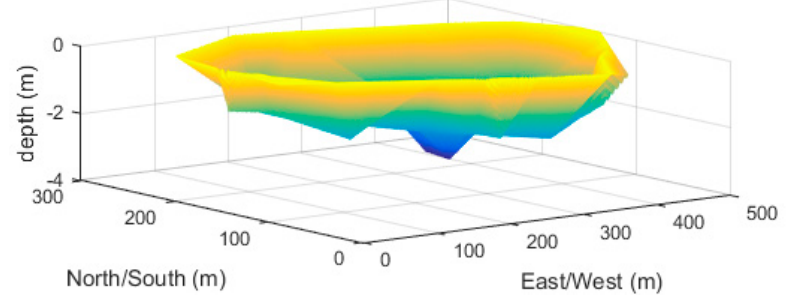

(a)

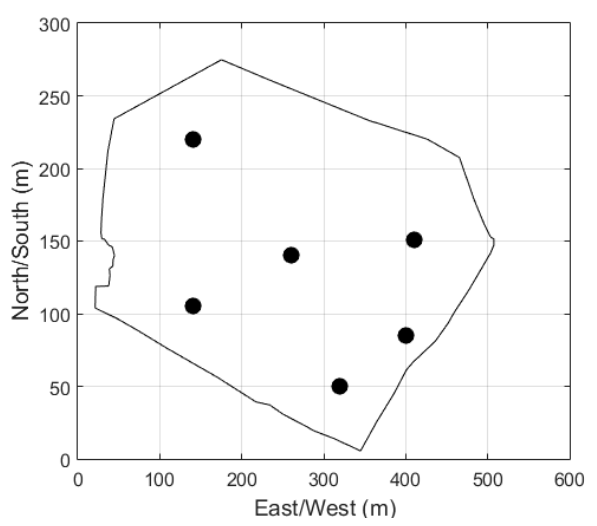

(b)

Figure 1. Profile and plain views of the bathymetry of the Pond Inlet wastewater stabilization pond (WSP). (a) Profile view of the Pond Inlet WSP bathymetry; (b) Plan view with sampling locations.

\subsection{Assessment of Water Quality}

Two trips to Pond Inlet were made in the summer of 2015, at the end of July and then again at the end of August in the final weeks of the treatment season. During each visit, five continuous days of sampling were undertaken. Six locations throughout the pond were selected for the collection of grab samples (500 $\mathrm{mL}$ for each location) and water quality and solar irradiance measurements. Raw wastewater samples were also collected from sewage trucks to represent the influent to the pond.

For all the sampling events, downwelling irradiance was measured from $290 \mathrm{~nm}$ to $700 \mathrm{~nm}$ using a calibrated JAZ-EL200-XR1 spectrometer suite manufactured by Ocean Optics (Largo, FL, USA). Measurements were recorded with smaller depth increments near the surface, as UV is sharply attenuated through the water column. Measurements were taken every $1 \mathrm{~cm}$ for the first $5 \mathrm{~cm}$, followed by $5 \mathrm{~cm}$ increments thereafter, until a signal was no longer observed. Temperature, DO and pH were measured using a HydroLab DS5-Multiparameter Data Sonde (Sutron, Sterling, VA, USA) unit within $10 \mathrm{~cm}$ of the water surface at each sampling location, as well as in raw samples.

\subsection{Detection of Indicator Organisms}

The effectiveness of pathogen removal in wastewater treatment is typically assessed through routine monitoring of the final effluent for the presence of indicator organisms such as E. coli, fecal coliforms or total coliforms. E. coli, other coliforms than E. coli, and total coliforms were measured during the July and August 2015 trips, to examine the disinfection performance of the WSP system at the beginning and end of the summer treatment season. Culture and enumeration of indicator organisms were carried out using the membrane filtration method according to the Standard Methods for the Examination of Water and Wastewater [31]. Chromocult coliform agar was used to prepare agar plates. The agar plates were able to differentiate E. coli (violet to blue colonies) from other coliforms (red colonies). Total coliforms were calculated as a sum of both E. coli and other coliforms. Samples were filtered with a filtration kit. The plates were cultured at a temperature of $37^{\circ} \mathrm{C}$ for $24 \mathrm{~h}$. Subsequently, the E. coli and total coliform colonies were enumerated.

\subsection{Modelling Disinfection}

Data sets were extended using interpolation via simple linear regression in order to compare predictions from existing models. The line of best fit was calculated using the least squares method for 
pH, DO, and temperature data. Artificial variability was generated with random noise from a normal distribution using the standard deviation of each data set. The result is shown in Figure 2.

Hourly sunlight data was interpolated by first using simple linear regression with the measured downwelling irradiance between the two sampling events. These measurements were taken roughly at noon. The line of best fit was calculated using the least squares method and random noise was used for variation. During Arctic summers, the hours of daylight extend to nearly $24 \mathrm{~h}$ a day. However, there is still hourly variation in sunlight intensity, and this variation intensifies toward the end of the treatment season as the number of sunlight hours decreases. Hourly variation in sunlight at the pond surface was approximated by Equation (1).

$$
I_{o}=S_{i} \sin \left(\frac{\pi t_{i j}}{24}\right)
$$

where $I_{o}$ in $\mathrm{W} / \mathrm{m}^{2}$ was the downwelling irradiance measured at the surface of the pond, $S_{i}$ was the daily peak irradiance in $\mathrm{W} / \mathrm{m}^{2}, t$ was the time where $i$ was the day, $j$ was the hour. If there was sunlight at the $j$ th hour of the $i$ th day, then $t_{i j}=t_{i j}$. If there was no sunlight at the $j$ th hour of the $i$ th day, then $t_{\mathrm{ij}}=0$.
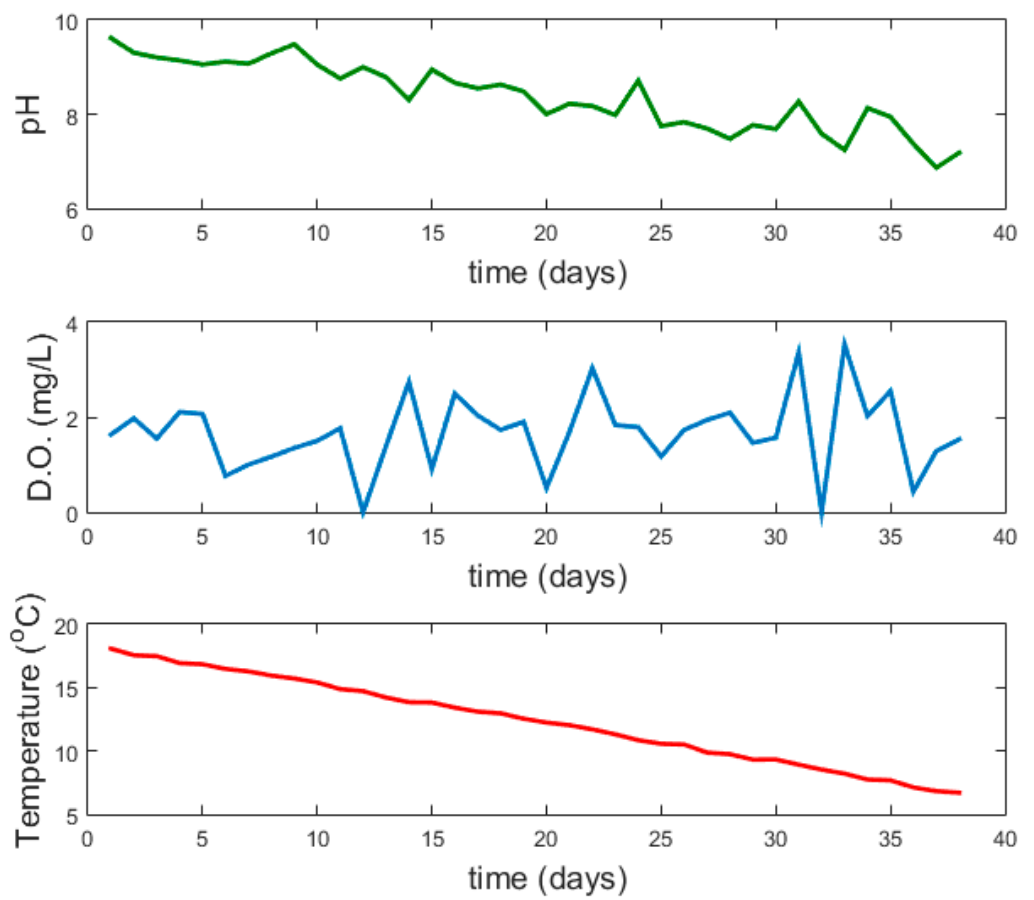

Figure 2. Synthesized data for $\mathrm{pH}$, dissolved oxygen (DO), and temperature based on statistics of collected data of sampling events 1 and 2 .

The simulations were performed from 26 July to 1 September for a total of 38 days. The measured bathymetry of the pond is shown by Figure 1a. However, the geometry was approximated, as shown in Figure 3, to simplify calculations.

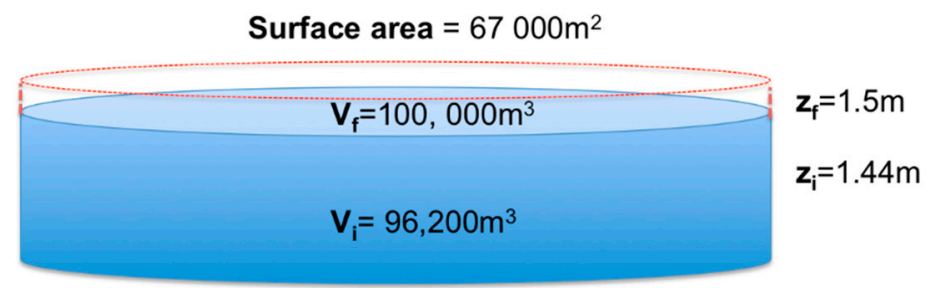

Figure 3. Approximated geometry of the Pond Inlet WSP for ease of calculations. 
The controlled discharge WSP had no outflow until the decant period prior to freezing. As such, the water level increased over the course of the treatment season, making this a non-steady-state hydraulic model. The volume of wastewater in the WSP at a given point in time $\left(V_{i}\right.$ in $\left.\mathrm{m}^{3}\right)$ is given by Equation (2).

$$
V_{i}=V_{i-1}+\left(Q_{i n}-Q_{o u t}\right) \Delta_{t}
$$

where $i$ was the day, $Q_{i n}$ was the flow rate into the pond in $\mathrm{m}^{3} / \mathrm{d}, Q_{\text {out }}$ was the wastewater outflow in $\mathrm{m}^{3} / \mathrm{d}$, and $\Delta_{t}$ was the time step of 1 day. $Q_{o u t}$ was zero because there was zero outflow. It was assumed that the daily inflow was pumped into the pond in a single event, daily at noon. The equation became

$$
V_{i}=V_{i-1}+\left(Q_{i n}\right) \Delta_{t}
$$

Changes in volume due to infiltration, evaporation, and precipitation were considered negligible and outside the scope of this study due to the lack of available data.

The spatial variation of indicator concentrations, $\mathrm{pH}, \mathrm{DO}$, and temperature in the pond were found to be minimal, and therefore a continuously stirred tank reactor (CSTR) model was employed. In addition, the low length to width ratio of the WSP supported the use of a CSTR model [32]. In addition, CSTRs have been shown to yield more conservative estimates for disinfection performance, which is safer for design [33].

First order models to represent disinfection in WSPs have been developed using first order kinetics by Chick's Law.

$$
\frac{d C}{d t}=-k(t) C
$$

where $C$ was the bacteria indicator concentration in CFU $/ 100 \mathrm{~mL}, t$ was the time in $\mathrm{h}$ or $\mathrm{d}$, and $k$ was the mortality constant in $\mathrm{h}^{-1}$ or $\mathrm{d}^{-1}$. Models have been developed to predict the mortality constant. Generally, the equation for the mortality constant was of the following form $[13,25,28,29]$ :

$$
k=k_{d}+k_{s} I
$$

or [26]

$$
k=k_{d} e^{x I}
$$

where $k$ was the mortality constant in $\mathrm{h}^{-1}$ or $\mathrm{d}^{-1}, k_{d}$ and $k_{s}$ were the dark and the irradiance disinfection rates, $I$ was the total solar irradiance incident upon the pond surface in $\mathrm{W} / \mathrm{m}^{2}$, and $x$ was the irradiation coefficient in $\mathrm{J} / \mathrm{cm}^{2} / \mathrm{d}$. The models considered in this study and the parameters used to predict the mortality rate are shown in Table 1 and have been previously reviewed elsewhere [34]. The first disinfection model for WSPs was developed by Marais, and it included only temperature and sunlight as factors for predicting disinfection [28]. However, there has been some contention as to whether temperature is one of the most influential factors in pathogen removal as the relationships between temperature and pathogen removal have been found to be highly variable $[5,9,21,24]$. Curtis et al., Auer and Niehaus, Mayo, and $\mathrm{Xu}$ included other important disinfection mechanisms and factors, such as $\mathrm{pH}, \mathrm{DO}$, and sedimentation, to their disinfection models $[13,25,26,29]$.

Table 1. Disinfection models predicting total coliform concentrations and their parameters.

\begin{tabular}{cc}
\hline Authors & Parameters \\
\hline Marais, 1974 [28] & Temperature, sunlight \\
Curtis et al., 1992 [13] & pH, DO, sunlight \\
Auer \& Niehaus, 1993 [25] & Sedimentation, depth-averaged sunlight \\
Mayo, 1995 [29] & pH, sunlight \\
Xu et al., 2002 [26] & temperature, depth-averaged sunlight \\
\hline
\end{tabular}




\section{Results}

\subsection{WSP Performance}

Figure 4a,b shows the attenuation of PAR (400-700 nm) and UV (290-400 nm) irradiance respectively in the Pond Inlet WSP. Approximately $80 \%$ of PAR was attenuated within the first $5 \mathrm{~cm}$ in water column, and over $90 \%$ was attenuated within the first $10 \mathrm{~cm}$. There was no PAR detection below $15 \mathrm{~cm}$ from the water surface. On the other hand, UV irradiance was attenuated more readily, with greater than $99 \%$ attenuated within the first $5 \mathrm{~cm}$ of the water column, and no UV detection below $5 \mathrm{~cm}$. The attenuation coefficient $\left(K_{d}\right)$ is an indication of how easily light penetrates the water column with depth. In this study, the average $K_{d}$ for PAR and UV were $29 \mathrm{~m}^{-1}$ and $80 \mathrm{~m}^{-1}$, respectively. The results aligned well with other findings, where UV light was reported to be attenuated within the first few centimeters of the water column and may not contribute significantly to overall pathogen removal $[7,35,36]$. Rather, it is likely that the longer wavelength, PAR, which penetrate deeper into the water column, could contribute more effectively to disinfection via exogenous photo-oxidation [7].

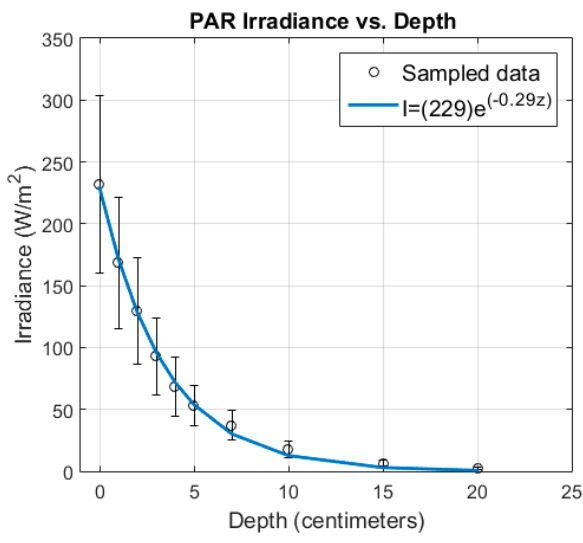

(a)

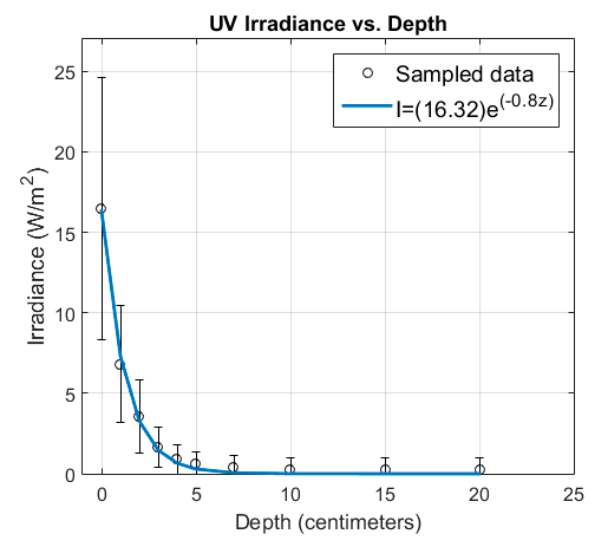

(b)

Figure 4. Light attenuation as a function of depth in the Pond Inlet WSP. (a) Spatial and temporal average of attenuation of PAR irradiance; (b) spatial and temporal average of UV irradiance.

The concentrations of $E$. coli, other coliforms and total coliforms in the influent and effluent are shown in Table 2. Overall, the single-celled system achieved 0.76-1.28 log removal of E. coli, 0.81-1.00 log removal of other coliforms and 0.79-1.02 log removal of total coliforms during the monitoring period of this study. In comparison to WSPs operated in temperate and tropical regions, 2-6 log removal of bacterial indicator organisms has generally been commonly achieved $[37,38]$. The log removal of E. coli, other coliforms, and total coliforms was higher in the August sampling event than in the July sampling event. This might be due to the long retention time in the WSP between the two sampling events and other pathogen removal mechanisms such as attachment and sedimentation. The second August sampling event took place one week prior to decant, and the average $E$. coli concentration in the pond was $1.3 \times 10^{6} \mathrm{CFU} / 100 \mathrm{~mL}$, a level which exceeded the NWB discharge standards of $10^{4}$ to $10^{6} \mathrm{CFU} / 100 \mathrm{~mL}$.

Table 2. Concentrations of indicator organisms in the influent and effluent of the Pond Inlet WSP.

\begin{tabular}{ccccccc}
\hline & Trip 1 (July) & & \multicolumn{3}{c}{ Trip 2 (August) } \\
\hline Indicator Organisms & Influent & Effluent & Log Removal & Influent & Effluent & Log Removal \\
\hline E. coli (CFU/100 mL) & $5.1 \times 10^{6}$ & $8.9 \times 10^{5}$ & 0.76 & $2.5 \times 10^{7}$ & $1.3 \times 10^{6}$ & 1.28 \\
Other coliforms (CFU/100 mL) & $1.8 \times 10^{7}$ & $2.8 \times 10^{6}$ & 0.81 & $1.1 \times 10^{8}$ & $1.1 \times 10^{7}$ & 1.00 \\
Total coliforms (CFU/100 mL) & $2.3 \times 10^{7}$ & $3.7 \times 10^{6}$ & 0.79 & $1.3 \times 10^{8}$ & $1.23 \times 10^{7}$ & 1.02 \\
\hline
\end{tabular}




\subsection{Comparative Analysis of Disinfection Models}

Models were evaluated based on their sensitivity to replicate important trends in the observed data and their ability to accurately forecast concentrations of fecal coliform in the pond.

Generally, models over-estimated the disinfection performance of the WSP by an order of magnitude or more, as shown in Figure 5. This includes the Marais model, which is commonly used for designing WSPs for disinfection [28]. This likely resulted from two things: first, the variables (e.g., temperature, $\mathrm{pH}$ ) extended beyond the range for which the models were designed, and second, the use of surface irradiance for quantifying the effect of sunlight rather than depth-averaged irradiance.

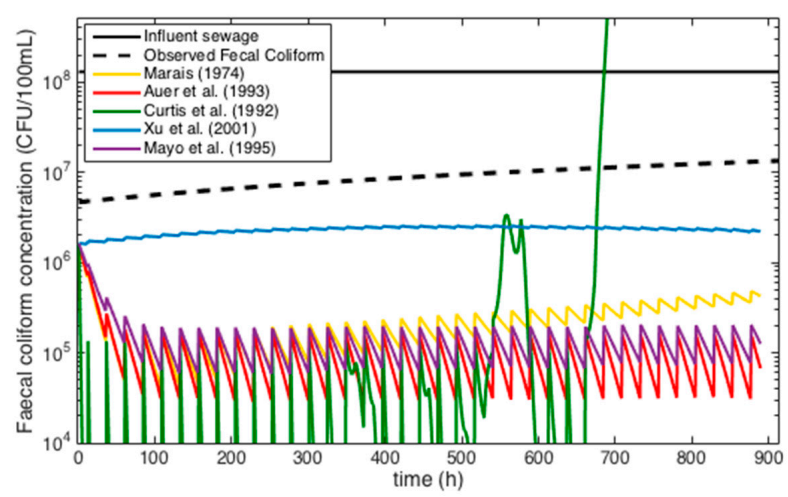

Figure 5. Observed fecal coliform concentrations (CFU/100 mL) compared with predicted concentrations by various disinfection models over the treatment season.

The total coliform concentration in the Pond Inlet WSP increased between the July and August sampling events by nearly an order of magnitude. The decrease in $\mathrm{pH}$, sunlight, and temperature were likely responsible for this observed trend. This increase in concentration corresponded to decreasing mortality rates, $k$, in the models as shown in Figure 6. The Xu et al. [26] and Auer and Nienhaus [25] models showed an increase, rather than decrease, in mortality rate over the course of the treatment season, while models that incorporated both sunlight and $\mathrm{pH}$ values predicted a decreasing mortality rate. This would suggest that exogenous photo-oxidation, which requires sunlight irradiance as well as a high $\mathrm{pH}$, would be an important disinfection mechanism in Northern WSPs.
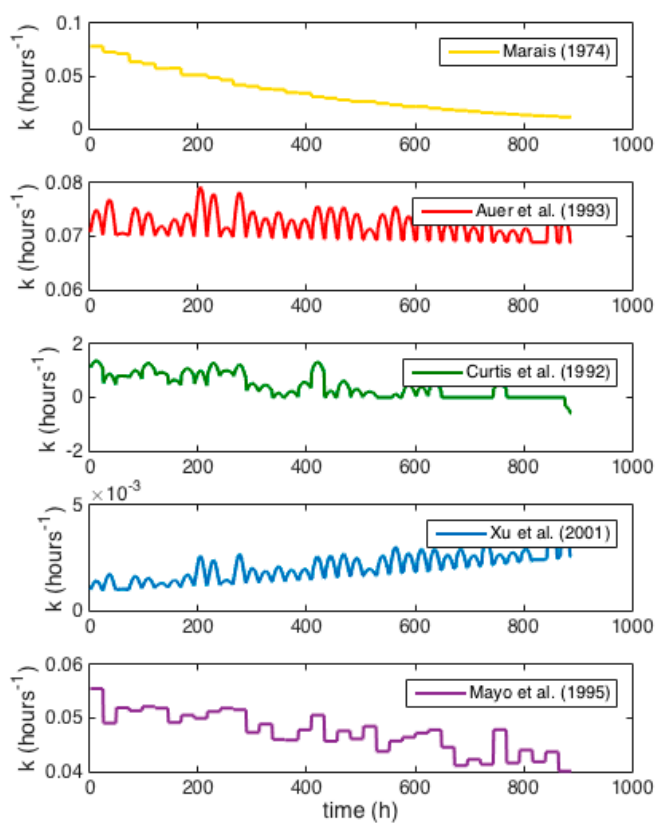

Figure 6. Predicted mortality rate constants $(k)$ of the 5 different models. 


\section{Discussion}

Sunlight inactivation of pathogens has been reported to occur as a result of three mechanisms: direct DNA damage by UV-B wavelength $(280-320 \mathrm{~nm})$, indirect endogenous damage caused by UV-B, and indirect exogenous damage involving UV-A (320-400 nm), UV-B, and PAR wavelengths [16]. The latter two mechanisms are known as photo-oxidation, which is a process where endogenous or exogenous sensitizers absorb light and transfer this energy to other molecules, catalyzing the formation of reactive oxygen species (ROS), which are toxic to microorganisms.

The results suggested minimal sunlight disinfection, which would only be effective at the surface of the pond. This was likely due to the high turbidity in the pond, as suspended solids and algal biomass are known to be two major constituents that influence the attenuation coefficient of WSPs [39]. Heaven et al. examined the overall attenuation coefficient $\left(K_{d}\right)$ for a range of suspended solid and algal concentrations, and found that the typical range varies between $5-25 \mathrm{~m}^{-1}$. This finding corresponds well with the results obtained in the Pond Inlet WSP [39].

The influent parameters were very similar for each of the sampling events. The influent $\mathrm{pH}$ was 7.3. The $\mathrm{pH}$ in the pond during the July sampling event was 9.4 , which could be attributed to algal activity. Algal blooms were observed during the July sampling event, but not during the August sampling event, where the $\mathrm{pH}$ was 7.4 , which was very similar to the influent $\mathrm{pH}$. Algal activity was most likely influenced by temperature and sunlight as the water temperature decreased from $17.5^{\circ} \mathrm{C}$ (July) to $7^{\circ} \mathrm{C}$ (August). Hence, it is likely that the lower temperature and reduced sunlight inhibited algal growth during the August sampling event.

It should be noted that the models included in this study (Table 1) were designed, validated, and calibrated with data collected from lower latitudes, in both temperate and tropical climates, rather than the Arctic. Frequently, the climatic parameter values recorded at Pond Inlet, particularly temperature and sunlight irradiance, were lower than those used to develop the models. For instance, the average daily peak surface irradiance in Pond Inlet was approximately $250 \mathrm{~W} / \mathrm{m}^{2}$. Compare this to irradiance values of $429-1096 \mathrm{~W} / \mathrm{m}^{2}$ used to calibrate the Curtis et al. model [35]. Extrapolating models can be difficult and unreliable. The $\mathrm{Xu}$ et al. model most closely replicated the performance of the Pond Inlet WSP [26]. This model was developed using year-round data from a pond in Noirmoutier, France. The winter climate in Noirmoutier is similar to the summer treatment season in Pond Inlet. Depth-averaged irradiance can be calculated by the following Equation:

$$
I=I_{0} / K Z\left(1-e^{-K Z}\right)
$$

where $I$ was the depth-averaged irradiance in $\mathrm{W} / \mathrm{m}^{2}, I_{0}$ was the surface irradiance, $K$ was the light attenuation coefficient, and Z was the depth of the WSP. This relationship incorporates both the depth of the pond and turbidity as being factors to consider for sunlight-mediated disinfection. The Curtis et al. strictly considered surface irradiance and was designed using clear tertiary wastewater [35]. As such, it would tend to over predict sunlight-mediated disinfection rates in the Pond Inlet WSP, which is effectively a single-celled primary pond with high turbidity. Moreover, as sunlight hours and $\mathrm{pH}$ decrease approaching the end of the treatment season, the model becomes unstable and greatly under-predicts disinfection performance in the Pond Inlet WSP. Hence, this model may be impractical for a number of Arctic communities that only have single or two-staged WSP systems with turbid wastewater.

\section{Conclusions}

This study investigated disinfection performance in an Arctic WSP. In order to maximize the disinfection power of the sun, a wastewater system could be designed with multiple cells in a series. This ecological engineering strategy would allow solids and organic material to settle in the primary cell, allowing sunlight to penetrate further into the water column in the lower turbidity water of the secondary cell. The comparative analysis of disinfection models showed that current models present challenges predicting disinfection performance in WSPs. Hence, a new model should be developed 
for Arctic application that considers relevant parameters and is calibrated with appropriate ranges of those parameters. In addition, sunlight should be quantified using depth-averaged irradiation in order to make the model more widely applicable.

Acknowledgments: The authors would like to thank the Government of Nunavut for their assistance in the field sampling, as well as the Canadian Water Network, the Canadian Northern Scientific Training Program (NSTP), the Natural Sciences and Engineering Council (NSERC), Queen's University, and the Canada Research Chairs program for providing funding in support of this study.

Author Contributions: Lei Liu and Alan MacDougall collected the field data in Pond Inlet; Lei Liu performed bacterial tests; Alan MacDougall performed nutrient tests; Lei Liu analyzed indicator organism and nutrient data; Alan MacDougall contributed to the modeling section; Lei Liu and Alan MacDougall drafted the article; Geof Hall and Pascale Champagne provided critical revision and final approval of the article.

Conflicts of Interest: The authors declare that they have no conflicts of interest.

\section{References}

1. Appendix B: Nunavut Regional Impact Analysis. Available online: https://www.itk.ca/wp-content/ uploads/2016/07/appendix-b.doc (accessed on 10 September 2016).

2. Al-Hashimi, M.; Hussain, H.T. Stabilization Pond for Wastewater Treatment. Eur. Sci. J. 2013, 9, 1857-7881.

3. Verbyla, M.E.; Iriarte, M.M.; Mercado Guzman, A.; Coronado, O.; Almanza, M.; Mihelcic, J.R. Pathogens and fecal indicators in waste stabilization pond systems with direct reuse for irrigation: Fate and transport in water, soil and crops. Sci. Total Environ. 2016, 551-552, 429-437. [CrossRef] [PubMed]

4. Davies-Colley, R.J.; Craggs, R.J.; Park, J.; Nagels, J.W. Optical characteristics of waste stabilization ponds: Recommendations for monitoring. Water Sci. Technol. 2005, 51, 153-161. [PubMed]

5. Pearson, H.W.; Marcon, A.E.; Melo, H.N. The removal of thermo-tolerant coliform bacteria by immobilized waste stabilisation pond algae. In Proceedings of the 8th IWA Specialist Group Conference on Waste Stabilisation Ponds, Belo Horizonte, Brazil, 26-30 April 2009.

6. Bolton, N.F.; Cromar, N.J.; Hallsworth, P.; Fallowfield, H.J. A review of the factors affecting sunlight inactivation of microorganisms in waste stabilisation ponds: Preliminary results for enterococci. Water Sci. Technol. 2010, 61, 885-890. [CrossRef] [PubMed]

7. Kadir, K.; Nelson, K.L. Sunlight mediated inactivation mechanisms of Enterococcus faecalis and Escherichia coli in clear water versus waste stabilization pond water. Water Res. 2014, 50, 307-317. [CrossRef] [PubMed]

8. Mezrioui, N.; Baleaux, B.; Troussellier, M. A microcosm study of the survival of Escherichia coli and Salmonella typhimurium in brackish water. Water Res. 1995, 29, 459-465. [CrossRef]

9. Ouali, A.; Jupsin, H.; Ghrabi, A.; Vasel, J.L. Removal kinetic of Escherichia coli and enterococci in a laboratory pilot scale wastewater maturation pond. Water Sci. Technol. 2014, 69, 755-759. [CrossRef] [PubMed]

10. Maynard, H.E.; Ouki, S.K.; Williams, S.C. Tertiary lagoons: A review of removal mechanisms and performance. Water Res. 1999, 33, 1-13. [CrossRef]

11. Awuah, E.; Anohene, F.; Asante, K. Environmental conditions and pathogen removal in macrophyte- and algal-based domestic wastewater treatment systems. Water Sci. Technol. 2001, 44, 11-18. [PubMed]

12. Fisher, M.B.; Iriarte, M.; Nelson, K.L. Solar water disinfection (SODIS) of Escherichia coli, Enterococcus spp., and MS2 coliphage: Effects of additives and alternative container materials. Water Res. 2012, 46, 1745-1754. [CrossRef] [PubMed]

13. Curtis, T.P.; Mara, D.D.; Silva, S.A. The effect of sunlight on faecal coliforms in ponds: Implications for research and design. Water Sci. Technol. 1992, 26, 1724-1738.

14. Maïga, Y.; Denyigba, K.; Wethe, J.; Outtara, A. Sunlight inactivation of Escherichia coli in waste stabilization microcosms in a Sahelian region. J. Photochem. Photobiol. 2009, 94, 113-119. [CrossRef] [PubMed]

15. Sinton, L.W.; Hall, C.H.; Lynch, P.A.; Davies-Colley, R.J. Sunlight inactivation of fecal indicator bacteria and bacteriophages from waste stabilization pond effluent in fresh and saline waters. Appl. Environ. Microbiol. 2002, 68, 1122-1131. [CrossRef] [PubMed]

16. Davies-Colley, R.J.; Donnison, A.M.; Speed, D.J. Towards a mechanistic understanding of pond disinfection. Water Sci. Technol. 2000, 42, 149-158.

17. Awuah, E.; Lubberding, H.J.; Asante, K. The effect of $\mathrm{pH}$ on enterococci removal in Pistia-, duckweed- and algae-based stabilization ponds for domestic wastewater treatment. Water Sci. Technol. 2002, 45, 67-74. [PubMed] 
18. Ansa, E.D.O.; Lubberding, H.J.; Ampofo, J.A.; Gijzen, H.J. The role of algae in the removal of Escherichia coli in a tropical eutrophic lake. Ecol. Eng. 2011, 37, 317-324. [CrossRef]

19. Ansa, E.D.O.; Lubberding, H.J.; Ampofo, J.A.; Amegbe, G.B.; Gijzen, H.J. Attachment of faecal coliform and macro-invertebrate activity in the removal of faecal coliform in domestic wastewater treatment pond systems. Ecol. Eng. 2012, 42, 35-41. [CrossRef]

20. Davies-Colley, R.J.; Bell, R.G.; Donnison, A.M. Sunlight inactivation of enterococci and fecal-coliforms in sewage effluent diluted in seawater. Appl. Environ. Microbiol. 1994, 60, 2049-2058. [PubMed]

21. Klock, J.W. Survival of coliform bacteria in wastewater treatment lagoons. J. Water Pollut. Control. Fed. 1971, 43, 2071-2083. [PubMed]

22. Mancini, J.L. Numerical estimates of coliform mortality rates under various conditions. J. Water Pollut. Control. Fed. 1978, 50, 2477-2484.

23. Flint, K.P. The long-term survival of Escherichia coli in river water. J. Appl. Bacteriol. 1987, 63, 261-270. [CrossRef] [PubMed]

24. Pearson, H.W.; Mara, D.D.; Mills, S.W.; Smallman, D.J. Physicochemical parameters influencing faecal bacterial survival in waste stabilization ponds. Water Sci. Technol. 1987, 19, 145-152.

25. Auer, M.T.; Niehaus, S.L. Modeling fecal coliform bacteria. 1. Field and laboratory determination of loss kinetics. Water Res. 1993, 27, 693-701. [CrossRef]

26. Xu, P.; Brissaud, F.; Fazio, A. Non-steady-state modelling of faecal coliform removal in deep tertiary lagoons. Water Res. 2002, 36, 3074-3082. [CrossRef]

27. Craggs, R.J.; Zwart, A.; Nagels, J.W.; Davies-Colley, R.J. Modelling sunlight disinfection in a high rate pond. Ecol. Eng. 2004, 22, 113-122. [CrossRef]

28. Marais, G.V.R. Fecal bacterial kinetics in stabilization ponds. J. Environ. Eng. Div. 1974, 100, 119-139.

29. Mayo, A.W. Modeling coliform mortality in waste stabilization ponds. J. Environ. Eng. ASCE 1995, 121, 140-152. [CrossRef]

30. Huang, Y.; Ragush, C.; Stea, E.; Jackson, A.; Lywood, J.; Jamieson, R.C.; Truelstrup Hansen, L. Removal of human pathogens in wastewater stabilization ponds in Nunavut. In Proceedings of the CSCE 13th International Environmental Specialty Conference, Halifax, NS, Canada, 28-31 May 2014.

31. Rice, E.W.; Baird, R.B.; Eaton, A.D.; Clesceri, L.S. Standard Methods for the Examination of Water and Wastewater, 22nd ed.; American Public Health Association, American Water Works Association, Water Environment Federation: Washington, DC, USA, 2012; ISBN 9780875530130.

32. Von Sperling, M. Modelling of coliform removal in 186 facultative and maturation ponds around the world. Water Res. 2005, 39, 5261-5273. [CrossRef] [PubMed]

33. Buchauer, K. Comparison of model approaches for predicting coliform removal in waste stabilization ponds. Water Environ. J. 2007, 21, 108-113. [CrossRef]

34. MacDougall, A. The Effects of Climate and Humic Substances on Disinfection Performance in Arctic Wastewater Stabilization Ponds. Master's Thesis, Queen's University, Kingston, ON, Canada, 2017.

35. Curtis, T.P.; Mara, D.D.; Dixo, N.G.H.; Silva, S.A. Light penetration in waste stabilization ponds. Water Res. 1994, 28, 1031-1038. [CrossRef]

36. Kohn, T.; Nelson, K.L. Sunlight-mediated inactivation of MS2 coliphage via exogenous singlet oxygen produced by sensitizers in natural waters. Environ. Sci. Technol. 2007, 41, 192-197. [CrossRef] [PubMed]

37. Reinoso, R.; Blanco, S.; Torres-Villamizar, L.; Bécares, E. Mechanisms for parasites removal in a waste stabilization pond. Microb. Ecol. 2011, 61, 648-692. [CrossRef] [PubMed]

38. Tyagi, V.K.; Sahoo, B.K.; Khursheed, A.; Kazmi, A.A.; Ahmad, Z.; Chopra, A.K. Fate of coliforms and pathogenic parasite in four full-scale sewage treatment systems in India. Environ. Monit. Assess. 2011, 181, 123-135. [CrossRef] [PubMed]

39. Heaven, S.; Banks, C.J.; Zotova, E.A. Light attenuation parameters for waste stabilization ponds. Water Sci. Technol. 2005, 51, 143-152. [PubMed]

(C) 2017 by the authors. Licensee MDPI, Basel, Switzerland. This article is an open access article distributed under the terms and conditions of the Creative Commons Attribution (CC BY) license (http:/ / creativecommons.org/licenses/by/4.0/). 